\title{
PERBANDINGAN INTENSITAS PEWARNAAN EKSTRAK BUAH TERUNG BELANDA (SOLANUM BETACEUM CAV) DENGAN DISCLOSING SOLUTION SEBAGAI BAHAN IDENTIFIKASI PLAK GIGI
}

\author{
Tri Yoga Suhedi ${ }^{1}$, Hafni Bachtiar ${ }^{2}$ Hidayati $^{1}$ \\ ${ }^{\mathbf{1}}$ Fakultas Kedokteran Gigi Universitas Andalas \\ ${ }^{2}$ Fakultas Kedokteran Universitas Andalas
}

\begin{abstract}
Plaque control is a procedure to prevent plaque accumulation on tooth surface that can be done with mechanic or chemical procedure. Using of mouthwash is an example of plaque control in chemical procedure. In this experiment, sunflower seed oil was used for mouthwash because it's compositions have activity toward plaque forming microorganisms. This study was meant to know the effect of sunflower seed oil on reducing dental plaque index. This study was a clinical experimental study using pretest and postest control group design. The samples of this study were the students of MA PGAI Padang. 30 students were divided randomly into two groups, a control group and a test group. The test group were given sunflower seed oil, and control group were given aquadest . Dental plaque score was measured with PHP index before and after intervention. The data analyzed by computer program with independent sample t-test and its significancy accepted if $p<0,05$. The results showed the significant differences of plaque index decrease after intervention, 0,66 for the control group and 1,26 for the test group. It can be conclude that gargling with sunflower seed oil can decrease the plaque index
\end{abstract}

Keywords: sunflower seed oil, dental plaque index

Affiliasi penulis: ${ }^{1}$ Fakultas Kedokteran Gigi Universitas Andalas Korespondensi: hidayati, email: hidayati@dent.unand.ac.id

\section{PENDAHULUAN}

Kesehatan gigi dan mulut adalah hal yang sangat penting untuk diperhatikan karena sangat berhubungan dengan kesehatan tubuh secara umum. Terganggunya kesehatan gigi dan mulut akan mengganggu kesehatan tubuh secara keseluruhan dan mengganggu aktivitas seseorang. ${ }^{1}$ Berdasarkan data RISKESDAS tahun 2013, prevalensi masalah kesehatan gigi dan mulut di Sumatera Barat meningkat menjadi $22,2 \%$ dimana penyakit yang paling banyak ditemukan adalah karies gigi dan penyakit periodontal. Data ini juga menunjukkan bahwa indeks DMF-T untuk provinsi Sumatera Barat adalah sebesar 4,7 yang menunjukkan bahwa kerusakan gigi masyarakat Sumatera Barat adalah sebanyak 470 gigi per 100 orang. ${ }^{2}$

Karies gigi dan penyakit periodontal adalah penyakit yang pada dasarnya disebabkan oleh aktivitas mikroorganisme patogen di dalam rongga mulut. Sekumpulan mikroorganisme tersebut membentuk komunitas yang kompleks dan berkembang dalam suatu matriks intraseluler yang dikenal dengan plak 
gigi. Plak berupa lapisan tipis, tidak berwarna dan lunak yang terdiri lebih dari 700 jenis bakteri dan melekat erat pada permukaan gigi. ${ }^{3}$ Pencegahan terbentuknya plak atau yang disebut juga dengan kontrol plak dapat dilakukan dengan tiga cara, yaitu secara mekanik, kimiawi, dan diet rendah gula. Kontrol plak secara mekanik dilakukan dengan menyikat gigi dengan rutin dan menggunakan dental floss. Pencegahan pembentukan plak secara kimiawi dapat dilakukan dengan berkumur menggunakan obat kumur. Obat kumur anti plak mempunyai kemampuan untuk mengurangi penyakit gigi dan mulut, diantaranya gingivitis, karies gigi, perikoronitis, dan kelainan mulut lainnya. ${ }^{4}$

Salah satu bahan yang digunakan untuk obat kumur adalah antiseptik, seperti klorheksidin. Penggunaan obat kumur dengan bahan kimia seperti klorheksidin dalam jangka waktu yang cukup lama dapat menimbulkan berbagai efek samping diantaranya pewarnaan pada gigi, hilangnya sensasi pengecapan, dan dehidrasi jaringan mukosa. ${ }^{4}$ Penelitian lebih lanjut telah dilakukan untuk mengatasi hal ini termasuk penggunaan bahan-bahan alami untuk mencegah penyakit gigi dan mulut. Di beberapa negara di Asia dan Afrika, 80\% dari populasi masih bergantung pada pengobatan tradisional, khususnya penggunaan bahan-bahan herbal. Biji bunga matahari adalah salah satu yang paling sering digunakan untuk menjaga kesehatan rongga mulut, terutama di India dan sekitarnya. $^{5}$ Pemakaian minyak biji bunga matahari untuk berkumur telah digunakan sejak ratusan tahun lalu oleh masyarakat India untuk mencegah karies gigi, bau mulut, penyakit gingiva, dan untuk memperkuat gigi. ${ }^{6}$

Penggunaan minyak tumbuhan termasuk minyak biji bunga matahari diperkenalkan oleh Dr. Fedor Karach, dimana penggunaannya terus meningkat setiap tahun termasuk di Indonesia. Di Amerika Serikat penggunaan minyak biji bunga matahari dikelompokkan dalam pengobatan tambahan dan alternatif. Menurut Departemen Kesehatan dan Pelayanan Masyarakat Amerika Serikat pada tahun 2008 terdapat lebih dari 200.000 penduduk yang menggunakan metode berkumur dengan minyak tumbuhan ini. ${ }^{8}$ Metode ini banyak digunakan karena prosedurnya yang mudah, yaitu hanya dengan menggunakan satu sendok minyak biji bunga matahari untuk berkumur selama 3-10 menit. Saat minyak telah masuk ke dalam mulut, minyak akan bercampur dengan saliva dan berubah menjadi berwarna putih susu. Selama 
prosedur tidak dibenarkan untuk menelan minyak karena telah bercampurnya bakteri dan toksin dengan minyak..$^{4,8}$

Pada biji bunga matahari terdapat minyak lemak dan asam organik. Penelitian fitokomia pada biji bunga matahari menunjukkan kandungan alkaloid, fitosterol, tanin, saponin, flavanoid, steroid, karbohidrat, lemak, dan minyak. Minyak biji bunga matahari berdasarkan hasil penelitian memiliki efek antimikroba. Penelitian yang dilakukan oleh Sroisiri Thaweboon pada tahun 2011 menunjukkan bahwa minyak biji bunga matahari mempunyai aktifitas antimikroba terhadap Streptococcus mutans, Lactobacilii spp, dan Candida albicans yang banyak ditemukan di plak. ${ }^{9}$ Penelitian juga menunjukkan penurunan jumlah bakteri Streptococcus spp yang terkandung dalam plak dan saliva pada orang yang berkumur menggunakan minyak biji bunga matahari. ${ }^{8}$

\section{Streptococcus mutans,}

Lactobacilii spp, dan Candida albicans sangat berperan dalam pembentukan plak, jika koloni mikroba tersebut diatas berkurang di rongga mulut, maka akumulasi plak di rongga mulut juga akan berkurang.
Penelitian ini dilakukan untuk menganalisis pengaruh berkumur menggunakan minyak biji bunga matahari dengan penurunan indeks plak pada permukaan gigi.

\section{METODE}

Kajian dalam penelitian ini mencakup pengaruh berkumur menggunakan minyak biji bunga matahari terhadap penurunan indeks plak. Kajian ini menggunakan rancangan penelitian dengan metode eksperimental klinis. Pengambilan sampel dilakukan dengan metode purposive sampling. Pengolahan data dilakukan dengan program SPSS melalui komputer menggunakan $T$ test, dengan derajat kepercayaan $95 \%$.

\section{HASIL DAN PEMBAHASAN}

Berdasarkan hasil penelitian diketahui siswa yang menjadi responden terbanyak yaitu perempuan sebanyak 22 orang $(73 \%)$ pada usia 16 tahun sebanyak 19 orang (63\%). Usia responden terendah yaitu 15 tahun sebanyak 2 orang (7\%) dan usia responden tertinggi yaitu 17 tahun sebanyak 9 orang (30\%).

Tabel 1. Rata-rata Indeks Plak Kelompok Sebelum dan Sesudah Berkumur dengan Aquades dan dengan

\begin{tabular}{|c|c|c|c|c|}
\hline \multirow{3}{*}{ Variabel } & \multicolumn{4}{|c|}{ inyak Biji Bunga Matahari $(n=15)$} \\
\hline & Berkumur & Iades & $\begin{array}{r}\text { Berkumu } \\
\text { Biji B } \\
\text { Mata }\end{array}$ & \\
\hline & $X \pm S D$ & $p$ & $X \pm S D$ & $p$ \\
\hline
\end{tabular}




\begin{tabular}{lllll}
\hline Pretest & $2,68 \pm 0,69$ & 0,002 & $2,93 \pm 0,99$ & 0,002 \\
\hline Postest & $2,03 \pm 0,56$ & $1,67 \pm 0,544$ & \\
\hline
\end{tabular}

Terdapat perbedaan rata-rata indeks plak sebelum berkumur dan setelah berkumur dengan aquades. Ratarata indeks plak sebelum berkumur adalah 2,68 $\pm 0,69$, dan rata-rata indeks plak setelah berkumur dengan aquades adalah 2,03 $\pm 0,56$. Perbedaan secara statistik menunjukkan hasil yang bermakna. Rata-rata indeks plak sebelum berkumur adalah 2,933 $\pm 0,99$ dan rata- rata indeks plak setelah berkumur dengan minyak biji bunga matahari adalah 1,673 $\pm 0,544$. Perbedaan secara statistik menunjukkan hasil yang bermakna.

Tabel 2. Selisih Hasil Rata-Rata Indeks Plak Berkumur Menggunakan Aquades dengan Berkumur Menggunakan Minyak Biji Bunga Matahari (n=15)

\begin{tabular}{cccc}
\hline Variabel & $\mathbf{n}$ & $\boldsymbol{X} \pm \boldsymbol{S D}$ & $\boldsymbol{p}$ \\
\hline Aquades & 15 & $0,66 \pm 0,498$ & \\
Minyak & 15 & $1,26 \pm 0,522$ & 0,004 \\
\hline
\end{tabular}

Tabel 2 menunjukkan bahwa selisih rata- rata indeks plak pada kelompok yang berkumur menggunakan aquades adalah 0,66 dengan standar deviasi 0,498 sedangkan pada kelompok yang berkumur menggunakan minyak biji bunga matahari adalah sebesar 1,26 dengan standar deviasi 0,522. Hasil uji statistik dengan Independent t-test didapatkan perbedaan bermakna dari selisih rata-rata indeks plak subjek penelitian dengan berkumur menggunakan aquades dan minyak biji bunga matahari.

Berdasarkan

Independent

Sample T-Test didapatkan bahwa nilai $\mathrm{p}$ $<0,05$ sehingga ada perbedaan yang signifikan antara kelompok kontrol yang berkumur aquades dengan kelompok perlakuan yang berkumur dengan minyak biji bunga matahari (Helinthus annuus L). Penurunan indeks plak subjek yang berkumur minyak biji bunga matahari 1,9 kali lebih banyak dibandingkan dengan kelompok berkumur dengan aquades.

Sesuai dengan teori yang dikemukakan oleh Pintaulli dan Hamada pada tahun 2010 bahwa pengendalian plak secara mekanis yang berupa penyikatan gigi dan flossing bisa disertai dengan upaya tambahan seperti penggunaan obat kumur untuk memberikan efektivitas pembersihan rongga mulut. Secara umum obat kumur merupakan larutan atau cairan yang digunakan untuk membilas rongga mulut dengan tujuan untuk membersihkan sisa makanan yang dapat menyebabkan plak yang tidak terjangkau ketika menyikat gigi, menghilangkan bau tak sedap, mempunyai efek terapi dan menghilangkan infeksi serta mencegah karies gigi. ${ }^{19}$

Hasil penelitian diperoleh data bahwa setelah tiga menit berkumur 
dengan minyak biji bunga matahari terjadi penurunan indeks plak secara signifikan, dibandingkan dengan berkumur dengan aquades. Hal ini dikarenakan berkumur dengan aquades yang tidak mengandung antibakteri hanya melarutkan dekstran ikatan $\alpha$ (16) pada plak gigi namun tidak menghambat pertumbuhan dan aktivitas bakteri yang terus membentuk plak baru setiap saat. Sedangkan responden yang berkumur dengan menggunakan minyak biji bunga matahari mengalami penurunan indeks plak yang signifikan dikarenakan selain melarutkan dekstran $\alpha$ (1-6), minyak biji bunga matahari memiliki kandungan tannin yang merupakan basis aktivitas antibakterial dengan merusak membran sel yang menyebabkan kebocoran Intraseluler. ${ }^{35}$

Selain itu, kandungan flavonoid pada minyak biji bunga matahari memiliki efek antibakteri karena kemampuannya berinteraksi dengan DNA bakteri dan alkaloid mampu mengganggu komponen penyusun peptidoglikan, sehingga dinding sel bakteri tidak terbentuk utuh. Mekanisme penghambatan flavonoid terhadap pertumbuhan bakteri karena kemampuan senyawa tersebut membentuk komplek dengan protein ekstraseluler, mengaktivasi enzim, dan merusak membran sel. Pada umumnya senyawa flavonoid dapat menghambat pertumbuhan bakteri gram positif dan gram negatif. Kandungan minyak biji bunga matahari yang bersifat bakterisid dan bakteriostatik menyebabkan aktivitas bakteri terhambat dan pembentukan plak setelah berkumur minyak biji bunga matahari dapat diturunkan. $^{36}$

Pada biji bunga matahari terdapat berbagai kandungan kimia yang memiliki aktivitas terhadap mikroorganisme pembentuk plak seperti alkaloid, fitosterol, tanin, saponin, flavanoid, steroid, karbohidrat, lemak, dan minyak. Penelitian yang dilakukan oleh Sroisiri Thaweboon pada tahun 2011 menunjukkan bahwa kandungan kimia yang terdapat pada minyak biji bunga matahari tersebut mempunyai aktifitas antimikroba terhadap Streptococcus sp, Actinomyces Viscous, dan Lactobacilii spp yang banyak ditemukan di plak khususnya pada tahap pembentukan kolonisasi awal, sehingga dapat menurunkan indeks plak setelah berkumur dengan minyak ini. ${ }^{10}$ Selain itu terjadi juga proses saponifikasi antara basa-basa alkali yang terdapat di dalam minyak dengan asam lemak yang akan menghasilkan gliserol dan garam yang bersifat seperti sabun, yaitu berbuih jika bertemu dengan air sehingga memiliki efek cleansing yang tinggi. ${ }^{8}$ 
Penelitian ini sesuai dengan penelitian HV Amith pada tahun 2007 mengenai efek berkumur dengan minyak biji bunga matahari terhadap plak dan gingivitis. Penelitian ini dilakukan pada 10 orang subjek yang diminta berkumur menggunakan minyak biji bunga matahari kemudian diukur indeks plak dan indeks gingiva. Hasil penelitian ini menunjukkan adanya penurunan pada indeks plak maupun indeks gingiva. ${ }^{6}$

Hasil penelitian ini juga sesuai dengan penelitian yang dilakukan oleh Asokan Sarath pada tahun 2009 tentang efek berkumur minyak tumbuhan terhadap plaque induced gingivitis. Pada penelitian ini digunakan berbagai jenis minyak tumbuhan seperti minyak zaitun, minyak wijen, serta minyak biji bunga matahari untk berkumur. Hasil penelitian ini menunjukkan penurunan indeks plak pada subjek penelitian setelah berkumur dengan minyak biji bunga matahari. Selain itu terdapat juga penurunan jumlah koloni bakteri yang dihitung pada plak subjek setelah berkumur dengan minyak biji bunga matahari. $^{7}$

Durai Anand pada tahun 2008 juga melakukan penelitian mengenai efek minyak biji bunga matahari terhadap bakteri penyebab karies gigi. Hasil penelitiannya menunjukkan bahwa minyak biji bunga matahari efektiv terhadap Streptococcus mutans dan Lactobacilus acidophilus.

\section{SIMPULAN}

Rata-rata penurunan indeks plak pada kelompok berkumur dengan aquades adalah $0,66 \pm 0,498$ serta ratarata penurunan indeks plak pada kelompok berkumur dengan minyak biji bunga matahari adalah $1,26 \pm 0,522$ dengan nilai $\mathrm{p}=0,004$ yang menunjukkan perbedaan yang bermakna. Penggunaan minyak biji bunga matahari untuk berkumur berpengaruh terhadap penurunan indeks plak.

\section{KEPUSTAKAAN}

1. Erick, Poul. Continuous Improvement of Oral Health in the 21st Century. WHO Global Oral Health Progaramme .2003

2. Laporan Riset Kesehatan Dasar. Jakarta: Litbang Departemen Kesehatan Republik Indonesia.2013

3. Carranza, Newman, Takei. Clinical Periodontology 11th Edition: Elsevier. 2009

4. Ann Felton, Chapman Alison, Simion Felton. Basic Guide to Oral Health Education and Promotion. 2009

5. Barathi Puroit, Abinavh Singh. Tooth Brushing, Oil Pulling, and Tissue Regeneration: A Review of 
Holistic Approches to Oral Health. 2011

6. Amith, H.V, Anil, Nagesh. L. Effect of Oil Pulling on Plaque and Gingivitis. J Oral Com Dent 2007; (1): $12-18$

7. Asokan, Rathan, Muthu MS, Ratna PV, Emmadi P, Raghuraman, Chamundeswari. 2010. Effect of Oil Pulling on Streptococcus mutans Count in Plaque and Saliva using Dentocult SM Strip Mutans Test: A Randomized, Controlled, Tripleblinded Study. Indian J Dent Res 2010; (19): 169

8. Pamela. E, Chamundeswari. Oil Pulling on Plaque Induced Gingivitis. Indian J Dent Res 2008; (20): 47-51

9. Gina Marie, Mc Combs, Lee Melvin. Oil Pulling: an Ancient Practice for a Modern Time. J Int Oral Health 2012; (4): 1-10

10. Westfelt E. Rationale of Mechanical Plaque Control. J Periodontol 1996; (3): 38-53

11. Smullen, J., Finnei, M., Storey, D.M., and Foster, H.A. 2012, Prevention of Artificial Dental Plaque Formation in vitro by Plant Extracts. Journal of Applied Microbiology, Centre for Parasitology and Disease Research, School of sEnvironment and Life
Sciences, University of Salford, Manchester, M5 4WT, U.K.

12. Cowan, M.M. Plant Product as Antimicrobial Agents. 1999. J. Microbiology Reviews12(4):564-582.

13. Thaweboon S, Nakaparskin, Thaweboon B. Effect of Oil Pulling on Oral Microorganisms in Biofilm Models. Asia J Pub Health 2011; 2 (2): $62-66$ 